Lieselot De Wilde, Bruno Vanobbergen \& Michel Vandenbroeck

\title{
2 "On voit bien que c'est un petit malheureux des Hospices". The Child, the Body and the Bath in Nineteenth-Century Belgium: a Cure for the Future?
}

This chapter focuses on the so-called 'unfortunate children' of the $19^{\text {th }}$ century children who, in the spirit of the age, allegedly were destined for criminality, as a result of their exposure to misery, neglect and poverty. ${ }^{1}$ Using Belgian case studies, we will show how unfortunate working-class children were reformed, and their parents made invisible, in order to minimise the risk of contaminating society. In the second half of the long $19^{\text {th }}$ century, Europe was facing a number of social policy problems, including a high infant mortality and a low life expectancy among the working classes. High infant mortality rates in particular came to be seen as an important problem in many European cities. ${ }^{2}$ In 1891 in the province of East Flanders, for example, 20 per cent of male new-borns passed away within the first year after birth. ${ }^{3}$ Parentless children, such as foundlings and abandoned children, had an even lower life expectancy. In 1863, Gustave Callier (1819-1863), alderman for education in the city of Ghent, described the "vondelingenschuif" installed at the hospital of St. Jan, where one could anonymously leave his/her (often sick) child, as a "murderous institute", since 62 per cent of the babies that were left there died in their first three months of

1 The quote in the title ("It is easy to see that it is an unfortunate child of the Hospices") referred to a (poorly clothed) child, abandoned by his/her parents and registered at the Council of Civil Hospices of Ghent. The child was placed in a family in a rural village. See: letter Jean Nové to secretary Council of Civil Hospices, 12 February 1912, BG 14, n 61, Council of Civil Hospices, Archives of the Bureau of Social Welfare (OCMW-Archief), Ghent, Belgium.

2 See: Alain Bideau et al., eds. Infant and Child Mortality in the Past (Oxford: Clarendon Press, 1997); Hugh Cunningham, Children and Childhood in Western Society since 1500 (New York: Longman, 1995); David S Barnes, The Making of a Social Disease: Tuberculosis in Nineteenth-Century France (Berkeley: University of California Press, 1995). For the situation in Belgium, see: Elise Plasky, La protection et l'éducation de l'enfant du peuple en Belgique. I. Pour les tout-petits (Brussels: Société belge de librairies, 1909).

3 Helmut Gaus, Politieke en sociale evolutie van België (Leuven: Garant, 2002), 102.

๑ OpenAccess. (c) 2019 Lieselot De Wilde, Bruno Vanobbergen \& Michel Vandenbroeck, published by De Gruyter. (cc) BY-NC-ND This work is licensed under the Creative Commons Attribution-NonCommercial-NoDerivatives 4.0 License. https://doi.org/10.1515/9783110581546-002 
life in the period $1830-1863 .{ }^{4}$ In fact, Ghent had an exceptionally high infant and child mortality. At the end of the $19^{\text {th }}$ century, more than one in four newborns in Ghent died during their first year, mostly as a result of an unhealthy diet. Bad living conditions and lack of personal hygiene explained the high child mortality. ${ }^{5}$

Overpopulation, the absence of sewerage and waterworks, pollution of watercourses and poor nutrition caused outbreaks of many diseases in the urban housing areas where the working classes were concentrated. Common diseases among the working classes were tuberculosis, syphilis (Venus disease), anaemia and rickets. Exceptionally high infant mortality and diseases such as tuberculosis were at the basis of high death rates in industrialised towns and cities such as Ghent and Verviers. ${ }^{6}$ The bourgeois class developed an unrelenting fear of the working classes and their epidemics. In addition to the fear of contamination of the higher social classes by the lower, the public was also afraid of contamination of the countryside by the city. Cities were seen as places of rampant diseases, destruction and death, while rural areas were glorified. The Belgian hygienist Hyacinthe Kuborn (1828-1912) said the following during a conference in 1876:

The existing difference between the city and the countryside is vital in terms of hygiene. Here, dispersion, healthy air and space. And there, concentration, oppressive and corrupt air, and a thousand harmful influences. ${ }^{7}$

The multitude of illnesses and epidemic diseases in cities were believed to be caused by the poor and their unhygienic living conditions, as well as by their lack of morality. In this way, health and virtue were linked intrinsically to one

\footnotetext{
4 Michel Steels, “De vondelingen te Gent in de $19^{\mathrm{e}}$ eeuw," Ghendtsche Tydinghen 3, no. 4 (1974): 139-140. Ghent was the last city to shut down their vondelingenschuif (rolle/tour) in 1863. For a broader context, see: Jean-Paul Bougard, "Des enfants trouvé en Belgique au début du XIXe siècle: le cas de Bruxelles de 1797 à 1826," in Enfance abandonnée et société en Europe, XIVe-XXe siècle. Actes du colloque international de Rome (30 et 31 janvier 1987) (Rome: École Française de Rome, 1991), $259-271$.

5 Jeroen Backs, "Mortality in Ghent, 1850 -1950. A Social Analysis of Death,” Belgisch Tijdschrift voor Nieuwste Geschiedenis 31, no. 3-4 (2001): 536-543.

6 For Verviers, see: Muriel Neven, "Epidemiology of Town and Countryside. Mortality and Causes of Death in East Belgium, 1850-1910," Belgisch Tijdschrift voor Nieuwste Geschiedenis 27, no. 1-2 (1997): 39-82.

7 Cited in Liesbet Nys, "Nationale plagen. Hygiënisten over het maatschappelijk lichaam," in De zieke natie, eds. Liesbet Nys, Henk De Smaele, Jo Tollenbeek and Kaat Wils (Groningen: Historische Uitgeverij, 2002), 224.
} 
another. ${ }^{8}$ For this reason, the working classes were seen as a danger to the reproduction of a healthy population which, in the eugenic spirit of the time, could disrupt the genetic quality of future generations. Poor families, and poor children in particular, became the focus of medical research in order to mitigate this risk. ${ }^{9}$ Authorities considered that the reorganisation of urban living environments could ameliorate or cure the "anti-social behaviour" of the lowest classes. ${ }^{10}$ At the same time, working men began to rebel against their poor working conditions and the effects of economic recession. The rioting and strikes of March 1886 shook Belgian society. Many workers all over Belgium became more willing to protest and demand reforms from employers and the government. In 1885, the socialists founded the Belgian Workers' Party, and over the next 15 years, they created a nationwide movement. ${ }^{11}$

During this time, children from the lower classes and their parents were seen as dangers to the future health of society. ${ }^{12}$ Consequently, "the protection of the child and the healthy status of the population became the domain of organisations, institutions, expertise and techniques". ${ }^{13}$ The increased focus on these children came from philanthropic societies, judicial and penal institutions and, later on, from the medical community. International publications from this time show how, for example in the United Kingdom and the Netherlands by the second half of the $19^{\text {th }}$ century, medicine had come to perceive itself as central to paediatric health through classification, treatment and institutions for 'at-risk children'. ${ }^{14}$ Historically, this focus on the 'child at risk' was aligned with attention to the 'abnormal child'. ${ }^{15}$ This fascination with the 'abnormal' dates back to 1795 at least, when Carl Friedrich Gauss (1777-1855) developed

8 See: Felix Driver, Power and Pauperism. The Workhouse System 1834-1884 (Cambridge: Cambridge University Press, 2004).

9 Michel Vandenbroeck, "The Persistent Gap between Education and Care: A "History of the Present” Research on Belgian Child Care Provision and Policy," Paedagogica Historica 42, no. 3 (2006): 363 -383; Bruno Vanobbergen and Nancy Vansieleghem, "Repairing the Body, Restoring the Soul: The Seaside Hospital of the City of Paris in Berck-sur-Mer and the French War on Tuberculosis," Paedagogica Historica 46, no. 3 (2010): 325-340.

10 Driver, Power and Pauperism, 14.

11 Carl Strikwerda, A House Divided. Catholics, Socialists and Flemish Nationalists in NineteenthCentury Belgium (Lanham: Rowman \& Littlefield Publishers, 1997), 109-111.

12 See: Christine Mayer, Ingrid Lohmann and Ian Grosvenor, eds., Children and Youth at Risk: Historical and International Perspectives (Frankfurt am Main: Peter Lang, 2009).

13 Vanobbergen and Vansieleghem, "Repairing the Body, Restoring the Soul," 326.

14 Ibidem, 327, 331.

15 Ingrid Lohmann and Christine Mayer, "Lessons from the History of Education for a 'Century of the Child at Risk'," Paedagogica Historica 45, no. 1-2 (2009): 1-16. 
his conception of the normal curve. ${ }^{16}$ This made it possible to compare every individual to 'the average'. Interest in outliers from the average arose from an atmosphere of fear; not so much of the 'abnormal person', but of the effect of abnormality on the social order. After all, a healthy society required a healthy race and healthy members. ${ }^{17}$ During the course of the $19^{\text {th }}$ and $20^{\text {th }}$ centuries, children (and their growth and development) were increasingly visualised through diagrams, tables and graphs. ${ }^{18}$ This led to an increased interest in tests and other measuring instruments to distinguish 'normal' children from 'abnormal' children. Scientification in the field of education, for example, led to the emergence of experimental pedagogy and pedology. ${ }^{19}$

In turn, this led to the design of pedagogical initiatives targeted at different categories of at-risk children. ${ }^{20}$ Institutions or interventions targeting these children included boarding schools, observation centres, alms-houses, holiday camps, infant day and night centres, orphanages and charity schools. The main aim of these often publicly funded initiatives was to limit future risks to both the child and society. Through the initiatives' focus on hygiene, morals and education, the authorities hoped to turn at-risk children into healthy adult citizens. By the end of the $19^{\text {th }}$ century, there was a growing consensus that the education and protection of children was no longer the sole responsibility of parents. Instead, governments came to be seen as necessary co-educators: "taking children into care and protection was a transformative act of governance - a social intervention by the local state to shape future conduct". ${ }^{21}$ In late $19^{\text {th }}$. century Belgium, local public and private interventions based on this idea included seaside hospitals, the care for abandoned children, and infant care centres/crèches and infant consultations. The history of these initiatives highlights the characteristics of the kind of childcare that was intended for the lowest socio-economic class. All were part of a broader program of philanthropic and public interest to protect the future of society.

16 See: Richard Herrnstein and Charles Murray, The Bell Curve-Intelligence and Class Structure in America (New York: Freepress, 2004).

17 See: Elise Plasky, La crèche et sa nécessité sociale. Conférence donné le 5 février 1910 à l'Exposition d'Hygiène des enfants du premier âge (Anvers: Buschman, 1910).

18 André Turmel, A Historical Sociology of Childhood: Developmental Thinking, Categorization and Graphic Visualization (Cambridge: Cambridge University Press, 2008), 66.

19 See: Marc Depaepe, Zum Wohl des Kindes?: Pädologie, pädagogische Psychologie und experimentelle Pädagogik in Europa und den USA, 1890-1940 (Leuven: Leuven University Press, 1993). 20 See Mayer, Lohmann and Grosvenor, eds., Children and Youth at Risk.

21 Ian Grosvenor, "Geographies of Risk: An Exploration of City Childhoods in Early Twentieth Century Britain,” Paedagogica Historica 45, no. 1-2 (2009): 229. 
An in-depth discussion of each of the above initiatives is beyond the scope of this contribution. Hence, this chapter highlights some specific procedures and practices from each initiative to illustrate the view of at-risk children as a sick body. Based on prior research by the authors, this contribution examines interventions aimed at the physical and moral reform of the so-called 'unfortunate children' of the $19^{\text {th }}$ century. First, this chapter discusses the change of perspective from 'delinquent children' towards 'unfortunate children' that is evident in international congresses on the protection of the child during the second half of the $19^{\text {th }}$ century. Second, this chapter analyses seaside hospitals in Wenduine and Middelkerke, the care for Ghent's abandoned children and the first crèches and infant consultations in some major Belgian cities. We examine these case studies from three different angles. First, we will discuss these interventions' perspectives on 'the child' by analysing narratives in photographs from the time. Next, we examine the notion of 'the body' in the idea of the scientification of risk. Finally, we look at 'the bath' as a metaphor for moral purification.

\section{The 'unfortunate children' of the nineteenth century}

Social policy in late $19^{\text {th }}$-century Europe was characterised by a change in attitude towards living conditions in urban centres. Different youth interventions had already been developed by this time, from alms houses over hospices to orphanages run by philanthropic or charitable considerations. However, the plight of parentless children only emerged on the political agenda in European countries during the last decades of the $19^{\text {th }}$ century, when several conferences on children without parents were held across Europe. The items on the conferences' agendas and the changing perspectives in debates on the protection of the child illustrate the emerging focus on these parentless children. The international penitentiary congresses, eight of which were held between 1872 and 1914, contributed to a widespread concern over 'the poor child'.22

Initially, the penitentiary congresses reported on the miserable conditions of children in prisons, including their abuse at the hands of adult inmates, and the

22 Les Congrès Pénitentiares Internationaux of Frankfurt (1846), Brussels (1847), Frankfurt (1857), London (1872), Stockholm (1878), Rome (1885), Saint Petersburg (1890), Paris (1895), Brussels (1900), Budapest (1905) and Washington (1910). See Marie-Sylvie Dupont-Bouchat, "Le mouvement international en faveur de la protection de l'enfance (1880-1914)," Revue d'histoire de l'enfance "irrégulière", 5 (2003): 208. 
subsequent risk of moral and physical contamination of these imprisoned children and the effect of this on society. The great promoters of these mid- $19^{\text {th }}$ century conventions were, first and foremost, prison inspectors, in particular Charles Lucas (1803-1889) from France and Édouard Ducpétiaux (1804-1868) from Belgium. ${ }^{23}$ From 1880 onwards, the protection of new groups of children (unfortunate children, abandoned or in danger) became a chief agenda item at several conferences, parting with the earlier emphasis on juvenile delinquency, as these children needed to be protected rather than punished. International conferences were dedicated to the protection of childhood, several of which took place in Belgium. ${ }^{24}$

Statistical reports of increasing numbers of delinquent children and worsening crime rates caused alarm in European countries in the late $19^{\text {th }}$ century. This led to the assumption that institutions and interventions for at-risk children had been ineffective and had produced recidivists instead of 'normal' children. Moreover, the existing institutions had become overpopulated due to increasing numbers of delinquent children. This did little to assuage the widespread public fear of poverty, crime and beggars. One lecture held in Brussels in 1857, for example, had the following title: "If you do not destroy pauperism, pauperism will destroy you". ${ }^{25}$ Vagabonds, abandoned children, or parentless children in general, were seen as embodying the features of potential risks to future society. The authors of an international, comparative study on Western policy concerning the protection of children between 1820 and 1914 argued how, in the last quarter of the century, a logic of punishment shifted towards a doctrine of re-education and protection. They described the change in public opinion as follows:

23 Dupont-Bouchat, "Le mouvement international en faveur de la protection de l'enfance," 207-208. Édouard Ducpétiaux was inspector-general of the Belgian prison system for 30 years. On Ducpétiaux, see: Bert Vanhulle, "Dreaming about the prison: Édouard Ducpétiaux and Prison Reform in Belgium (1830 - 1848)," Crime, Histoire \& Sociétés/Crime, History \& Societies 14, no. 2 (2010): 107-130.

24 Dupont-Boucat, "Le mouvement international en faveur de la protection de l'enfance," 210. See also: Catherine Rollet, "La santé et la protection de l'enfant vues à travers les Congrès internationaux (1880-1920),” Annales de démographie historique 101, no. 1 (2001): 97-116. The first international conference exclusively dedicated to the protection of children took place in Paris in 1889. In October 1890, the Congrès International pour l'Étude des Questions Relatives au Patronage des Détenus et à la Protection des Enfants Moralement Abandonnés (International Conference for the Study of Questions relating to Patronage of Detainees and the Protection of Morally Abandoned Children) took place in Antwerp. This conference was a big success, with 124 foreign attendants. See chapter 8 in this volume for more information on the broader role of this conference.

25 Cited in Romain Vanlandschoot, Sluit ze op... Jongeren in de criminaliteit, 1400 tot nu (Leuven: Davidsfonds, 2008), 186. 
Feeling sorry for unfortunate children when they are inoffensive, punishing them when they are guilty will not suffice any longer. It is necessary to consider them as victims of neglecting or unworthy parents. They need education and protection. This has to be done because the unfortunate, abandoned child is a danger for society. ${ }^{26}$

This oscillating focus on the endangered and the dangerous, on the culpability of abusing parents and that of their abused children, and on the innocent past and compromised future featured in discussions on the "enfant moralement abandonné" ('morally abandoned child') and "la déchéance de la puissance paternelle" ('the decay of parental authority'). ${ }^{27}$ At-risk children were seen as children exposed to misery, desolation and parental neglect. ${ }^{28}$

\section{The innocent dangerous child}

From 1880 to 1890, reformers worked to develop systems focused on prevention rather than repression. Debates on social policy at this time were dominated by the question of whether at-risk children were to blame for their plight. This discussion led to the idea of the "innocent criminal child". ${ }^{29}$ For example, the opening session of the penitentiary conference in St. Petersburg in June 1890 focused on "l'enfant malheureux". ${ }^{30}$ The international conference on patronage and the protection of socially abandoned children, organised in Antwerp a few months later, established a modern definition of 'children at risk': "children who, due to weaknesses, negligence, serious errors of the parents or others are left to themselves and deprived of education". ${ }^{31}$

This idea arose from crime prevention efforts, amidst an emerging understanding that incarceration alone could not address the problem of criminality.

26 Marie-Sylvie Dupont-Bouchat and Eric Pierre, eds., Enfance et justice au XIXe siècle. Essays d'histoire comparée de la protection de l'enfance 1820-1914. France, Belgique, Pays-bas, Canada (Paris: Presses Universitaires de France, 2001), 257.

27 Sylvia Schafer, Children in Moral Danger and the Problem of Government in Third Republic France (Princeton: University Press, 1997), 73; Carine Steverlynck, Kleine martelaars. Een historisch document over misbruikte kinderen, kindermishandeling, incest en prostitutie (Antwerp: Icarus, 1997), 260.

28 Juliane Jacobi, "Between Charity and Education: Orphans and Orphanages in Early Modern Times," Paedagogica Historica 45, no. 1-2 (2009): 51-66.

29 See: Chris Leonards, Ontdekking van het onschuldige criminele kind (Utrecht: Verloren, 1995). 30 Dupont-Bouchat, "Le mouvement international en faveur de la protection de l'enfance," 213. 31 Cited in Marie-Sylvie Dupont-Bouchat, Les pénitenciers pour enfants en Belgique au XIXe siècle (1840-1914) (Louvain-la-Neuve: Commission internationale pour l'histoire des Assemblées d'États, 1996), 82. 
The evolution towards protection and re-education emerged from philanthropic networks and patronages of "the fathers and mothers of the movement of children at risk". ${ }^{32}$ These so-called 'educational children' were seen as children deprived of good parenting. This led to the creation of novel categories of at-risk children, also known as abandoned children, foundlings, vagrants and orphans. During this period, categories emerged such as "l'enfant en danger", "l'enfant morallement abandonné", "l'enfant incorrigible" and "l'enfant martyr". ${ }^{33}$ These concepts had become in vogue by the end of the $19^{\text {th }}$ century, and were discussed and approved by the international conferences held in St. Petersburg and Antwerp in 1890.

The debates and agendas of subsequent penitentiary conferences further developed this idea. This led to a growing consensus that crime rates would drop, and eventually disappear, if society could protect these children. These debates illustrate that at-risk children were no longer regarded as criminals, but as children in need of state protection and support from private philanthropic societies that operated as legal substitutes for the children's parents. The notion of risk replaced the focus on intervention, with an abstract combination of factors designating statistical sets as 'populations at risk' based on probability rather than cause. ${ }^{34}$ More recently, this concept of 'the child at risk' has been discussed extensively in international literature. ${ }^{35}$ Children who had fluctuated between being at risk and becoming a risk became the subject of intervention. In this way, the child at risk had many faces:

32 Jeroen Dekker, "Children at Risk in History: A Story of Expansion," Paedagogica Historica 45, no. 1-2 (2009): 18.

33 Dupont-Bouchat, “Le mouvement international en faveur de la protection de l'enfance," 209; Cynthia Connolly, Saving Sickly Children. The Tuberculosis Preventorium in American Life, 19091970 (New Brunswick: Rutgers University Press, 2008), 17.

34 Robert Castel, "De la dangerosité au risqué,” Actes de la recherche en sciences sociales 47-48 (1983): $119-127$.

35 Nelleke Bakker, Sjaak Braster, Marjoke Rietveld-Van Wingerden \& Angelo Van Gorp, eds., Kinderen in gevaar. De geschiedenis van pedagogische zorg voor risicojeugd. Jaarboek voor de geschiedenis van opvoeding en onderwijs 2007 (Assen: Van Gorcum, 2007); Jeroen Dekker, Het verlangen naar opvoeden (Amsterdam: Uitgeverij Bert Bakker, 2006); Mayer, Lohmann and Grosvenor, eds. Children and Youth at Risk; 'Special Issue: Children and Youth at Risk', Paedagogica Historica 45, no. 1-2 (2009): 1-264; Bruno Vanobbergen, "Belgian Seaside Hospitals and the Child at Risk: Exploring an Educational Paradox," Journal of the History of Childhood and Youth 2 (2009): 234-248. 
'At risk' as a category was then filled in many ways, ranging from presumed problem behaviour by children and youths and the families they came from to children and youths with a particular physical or mental handicap. ${ }^{36}$

\section{The out-of-home placed child}

Debates began to focus on how the protection of the state should be organised. Governments discussed how to address the question of parentless children: should they be placed in foster families or in residential care? Which substitute education was best for children who could not continue living with their parents? ${ }^{37}$ Medical doctors set the tone in this debate. However, in addition to the question of where children needed to stay, people also discussed the provision of adequate medical care. This included appeals for better access to sterilisation and distribution of milk to combat child mortality.

This contributed to the rise of the hygienic movement, which assigned social dimensions to the concept of disease. ${ }^{38}$ At its roots was an analogy between parts of the human body and 'the social body' or 'the people's body' ("volkslichaam"). If the lower social classes were affected by diseases, both physically and morally, the rest of society was in danger as well. In this way, children in poverty were considered a body that suffers from various diseases. Hygienists considered cities more and more as places to be avoided by (poor) children, given the increasing number of people suffering from alcoholism, tuberculosis and syphilis. ${ }^{39}$

Social progress was deemed impossible if the situation of at-risk children was left untouched. This perception of childhood was linked to the then prevailing fear of degeneration and destabilisation of society, as described by the Liège hygienist Gustave Jorissenne (1846-1924):

The viability of a nation depends on a correct understanding of all parts: the misfortune of the small spread to the grownups; an epidemic remains not only a threat for the destitute, it also affects the upper class, like the skipping flames of a burning hut can burn palaces in

36 Bruno Vanobbergen and Frank Simon, “ 'Merci à tous et à toutes de votre propagande, si pleine de charme et de sourires': On Tour with the Socialist Travelling Colony Gentse Volkskinderen (1898-1915)," History of Education 40, no. 3 (2011): 316.

37 Marjoke Rietveld-van Wingerden, Kind in gevaar: reden tot uithuisplaatsing? De vereniging Tot Steun als zorgverlener in een veranderende wereld van de kinderbescherming en jeugdzorg 18861998 (Antwerp: Garant Uitgevers, 2017).

38 Nys, "Nationale plagen. Hygiënisten over het maatschappelijk lichaam," 220-241.

39 Ibidem, 224. 
ashes; the moral decay is contagious from low to high and similarly high to low; social disturbances spoil the whole national organism. ${ }^{40}$

All of this resulted in the development of a comprehensive European program during international penitentiary conferences and conferences on patronage and the protection of childhood held in Antwerp (1890, 1894 and 1898), Paris and Brussels (1900). The program included four key elements: legislative reform, institutional reform, the promotion of "le patronage" ${ }^{41}$ and the reform of the juvenile justice system through the establishment of juvenile courts in accordance with the Anglo-Saxon model. ${ }^{42}$ By this time, initiatives to protect working-class children were in effect across Europe: "In the nineteenth century, attacking the problem of at-risk children, to be found only among the lower strata of society, was seen as a tough job to be coped with successfully within a measurable time". ${ }^{43}$ People assumed that improving the urban environments of the children of the labour class would solve poverty, criminality, ill health, alcoholism, delinquency and degeneracy. These diseases of the lower class were summarised as "anti-social behaviour". Improvements in the appalling living conditions in urban areas would improve health as well as virtue, which were linked intrinsically to one another. The body of the child was considered the best way to morally cure the future social body. ${ }^{44}$

\section{Exploring the child as a sick body: The child, the body and the bath.}

Three examples of Belgian educational interventions based on this idea are the seaside hospitals in Wenduine and Middelkerke, the care for the abandoned children of Ghent, and the first crèches and infant consultations in major Belgian

40 Cited in Nys, “Nationale plagen. Hygiënisten over het maatschappelijk lichaam,” 223.

41 For the role of Jules Lejeune (1828-1911), Minister of Justice in Belgium between 1887 and 1894, in promoting the patronage of delinquent and abandoned children by committees consisting of bourgeois elites, as a means of social control, see: Stef Christiaensens, Tussen klassieke en moderne criminele politiek. Leven en beleid van Jules Lejeune (Leuven: Universitaire Pers Leuven, 2004), 407-409.

42 Dupont-Bouchat, "Le mouvement international en faveur de la protection de l'enfance," 214. For the history of the Belgian Child Protection Act of 1912, see chapter 1/introduction to this volume.

43 Dekker, "Children at Risk in History: A Story of Expansion," 35.

44 Driver, Power and Pauperism, 65. 
cities such as Antwerp, Brussels, Ghent and Liège. We will outline each case study briefly. More detailed information on each case study is available in existing published work by the authors.

The first seaside hospitals emerged in Europe between 1860 and 1880, with the first pioneering initiatives taken in France and Italy..$^{45}$ Seaside hospitals were developed based on the perceived benefits of fresh air for children's health, declining public health and the need for a moral reclamation of the nation. Belgium was a late adopter of seaside hospitals, much to the outrage of Belgian hygienists. Attendees at the Hygiene Congress in Brussels in 1876 raised this issue. Soon after, the General Council of the Civil Hospices of Brussels initiated the construction of a seaside hospital. ${ }^{46}$ However, the Council lacked the funds to build its own hospital and decided to pursue other options. The Council eventually decided to cooperate with François Van Den Abeele (1824-1900) who had just completed the construction of a private seaside hospital for weak children in Wenduine, a small town on the Belgian coast. From this point onwards, at-risk children were sent from Brussels to Wenduine. In the meantime, however, Viscount Roger de Grimberghe (1830 - 1879) died on 27 November 1879 in Brussels and in his will left half a million Belgian francs to the General Council. The money was to be used to create "a hospital for poor and rachitic children from the Brussels region, which should be given the name 'Hôpital Maritime Roger de Grimberghe'". ${ }^{47}$ The dunes of the sea town of Middelkerke were chosen as the location. The construction of the hospital began in 1882 and the first ill children were set to arrive on 6 November 1884. The seaside hospital in Wenduine would last until 1899; the one in Middelkerke was destroyed at the end of the First World War. ${ }^{48}$

45 J. Uffelmann, "Ueber Anstalten und Einrichtungen zur Pflege unbemittelter scrophulöser und schwächlicher Kinder, insbesondere über Seehospize, Soolbäderheilstätten, ländliche Sanatorien, Reconvalescenzhäuser und Feriencolonieen," Vierteljahrsschrift für Gesundheitspflege 12, no. 4 (1880): 697-742.

46 During construction of the seaside hospital of Middelkerke, the Ministry of the Interior was responsible for public health affairs. However, Belgium's central administration played a modest role in public health at that time. It was only after the First World War that Belgian government authorities increased their radius of action. Until then, public health mainly was managed by local communities. The two most important local authorities were the Commissions des Hospices Civiles ('Councils of the Civil Hospices') and the Bureaux de Bienfaisance (Social Welfare Councils), established by the laws of October 7, 1796 and November 27, 1796 respectively.

47 See: Placement des enfants atteints de rachitisme ou de scrofulose dans l'hôpital maritime du Dr Van den Abeele, 1878-1883, n² 251/1, Council of Civil Hospices, General Fund, Archives of the Bureau of Social Welfare (OCMW-Archief), Brussels, Belgium.

48 For more info, see: Van Obbergen, "Belgian Sea Hospitals". 
The second case study is the care for the abandoned children of Ghent. Children were labelled 'abandoned' by the Council of Civil Hospices through an application letter, which was usually written by the mother of the child (which means that, contrary to foundlings, the parents were known). This initiated a police investigation to complete a "Déclaration d'abandon d'enfant" in order to register the child. Next, a written request was sent to the hospice of the sisters of Childhood Jesu (zusters Kindsheid Jesu) to accept the child on a temporary basis, regardless of its age and gender, until the moment a suitable wet nurse and family were found. The congregation of the sisters of Childhood Jesu was established in 1835 to organise a home for foundlings and a children's hospital in the hospice of Sint-Jan-in-d'Olie. There, the sisters took care of foundlings, abandoned and sick children in difficult material circumstances, without any form of comfort. $^{49}$

In July 1871, the congregation, together with the abandoned children, moved to a hospice in Schreiboom, in the city centre of Ghent ('Kortrijksepoortstraat'). From this point onwards until the First World War, the care of abandoned children and foundlings was regulated in Schreiboom through a convention with the Council of Civil Hospices. ${ }^{50}$ Subsequently, the city of Ghent gradually stopped naming it an 'institution' for abandoned children, since, in theory, the children only had to stay there for a short period of time before being allocated to families on the countryside. However, annual reports from this time show that, in practice, some children stayed at Schreiboom for months or years on end. Furthermore, Schreiboom served as a stopover for abandoned children moving from one foster family to another, or if the child needed medical care in the city of Ghent.

The third case study concerns the first crèches and infant consultations that emerged in urban areas of Belgium, initiated by bourgeois philanthropic and religious groups. The first Belgian crèche, for children from zero to three years of age, was founded in Brussels in 1845. In 1869, the Societé de Bienfaisance pour l'Établissement de Crèches à Gand established the first private crèche in Ghent. By the early $20^{\text {th }}$ century, 51 crèches provided care for 3500 Belgian children. The crèches were intended for the lowest socio-economic classes and kept a

49 For the history of this congregation, see: Karel Strobbe and Kristien Suenens, Zusters Kindsheid Jesu, 1835-2010 (Ghent/Leuven: Zusters Kindsheid Jesu/KADOC, 2010).

50 Rapport sur la convention concernant la garde des enfants trouvés et abandonnées, s.d. and letter secretary Council of Civil Hospices to Jean Nové, 17 August 1901, BG 14, n² 28, Council of Civil Hospices, Archives of the Bureau of Social Welfare, Ghent. 
clear distance between the parents and the staff. ${ }^{51}$ Infant consultations were organised to advise young mothers on hygienic rules they needed to follow in raising their babies. The first infant consultation was founded in Brussels in 1897. ${ }^{22}$ Interventions were designed to rescue children from their original living and education environments. Parents were often made invisible. We will analyse the seaside hospitals, the care for the abandoned children of Ghent, and the first Belgian crèches and infant consultations from three perspectives. Each case study illustrates initiatives aimed at the physical and moral reform of the 'unfortunate children' of the $19^{\text {th }}$ century.

\section{The child}

The first part of this analysis focuses on the imagery used by each initiative to frame the child at risk. The use of visual materials has become quite common in the history of education, but not a lot of photographs of late $19^{\text {th }}$-century to early $20^{\text {th }}$-century child care initiatives are available for study. ${ }^{53} \mathrm{An}$ in depth visual analysis of each selected image is beyond the scope of this contribution. Instead, we will examine three photographs that typify the imagery and narratives of each case study. In line with the work of Sonja K. Foss, we studied these images from the perspective of the photographer, but also sought to discover what "action the image communicates". ${ }^{4}$ We wanted to know the messages these images intended to convey to their audience. To answer this question, we focused mainly on what is portrayed explicitly in or is absent from the selected photographs. In other words, we were interested in what the photos revealed through what they included or excluded. In this way, we apply "a rhetorical analysis of the visual" - in which we explore how visual artefacts are embedded in a specific historical context and discourse. ${ }^{55}$

51 For more info on the origins of Belgian childcare, see chapter 3 in Michiel Vandenbroecke, In verzekerde bewaring. Hondervijftig jaar kinderen, ouders en kinderopvang. 4e editie (Amsterdam: Uitgeverij SWP, 2014).

52 Karel Velle, "Hygiëne en preventieve gezondheidszorg in België (ca. 1830-1914). Bewustwording, integratie en acceptatie” (Thesis, Rijksuniversiteit Gent, 1981), 87.

53 For a reflection on the 'visual turn' in the history of education, see chapter 1/introduction to his volume.

54 Sonja K. Foss, Rhetorical Criticism: Exploration and Practice, 3rd edition (Long Grove, IL: Waveland Press, 2004), 216.

55 Cara Finnegan, "Doing Rhetorical History of the Visual: The Photograph and the Archive," in Defining Visual Rhetorics, eds. Charles A Hill and Marguerite Helmers (London: Lawrence Erlbaum Associates, 2004), 95-214; Heidi Degerickx, Griet Roets, Kris Rutten and Angelo Van 


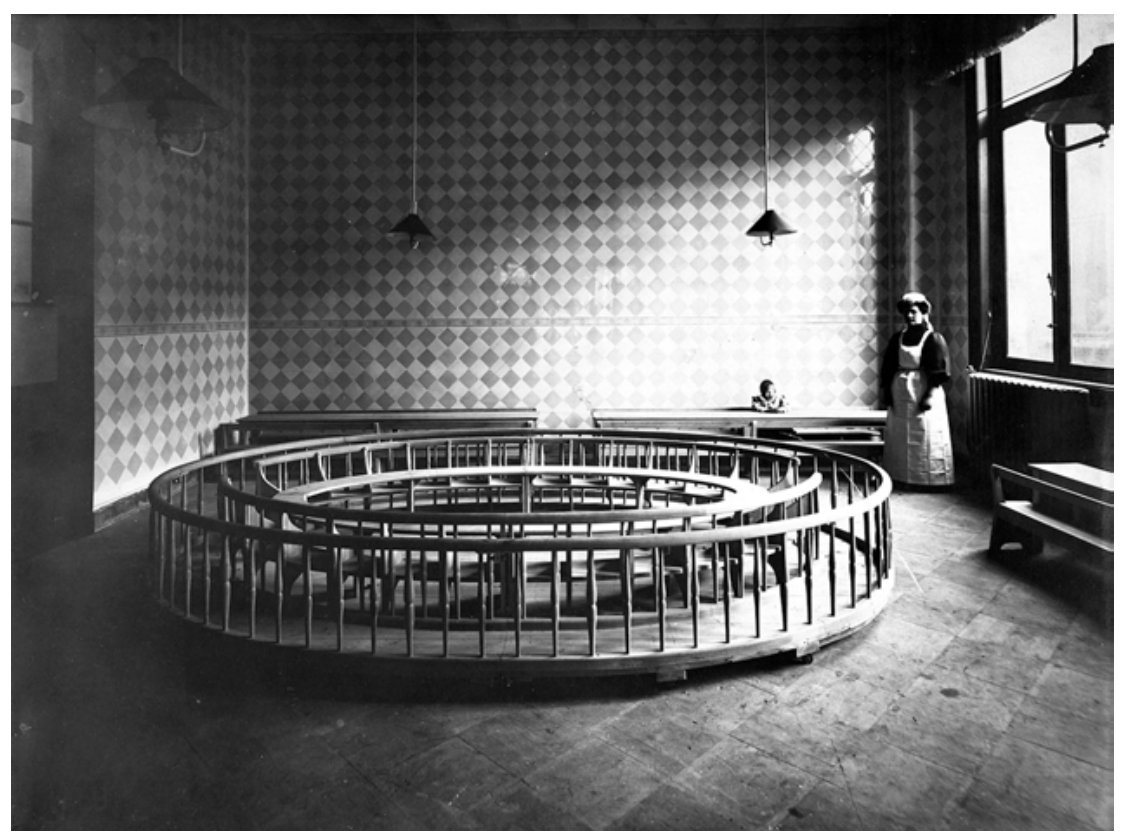

Fig. 2.1: Photograph of one of the first infant care centres in Antwerp, early $20^{\text {th }}$ century. One of the authors received this photo (without reference or date) from a person in charge of an Antwerp crèche.

As the first step in our analysis, we considered whether each photo included children. As seen in Figures 4.1 and 4.2, the selected images of the seaside hospital in Middelkerke and an early Antwerp day-care centre do not include children, in spite of the fact that these institutions were intended to accommodate large groups of children for long periods of time. Joseph Casse (1841-1915), the first medical doctor in the Middelkerke seaside hospital, printed postcards of the seaside hospital for the children to use when writing to their families. These postcards supported Casse's efforts to present the institution as a scientific enterprise; the postcards showed the hospital's sterilisation kettle, surgery room, refectory and dormitories. The images presented a clean, neat medical worksite characterised by order and regularity, unspoilt by the chaos and disorder caused by 20 children returning from the beach.

Gorp, "What Kind of Silence is Being Broken?: A Visual-rhetorical History of the Out-of-home Placement of Children in Poverty in 1990s Belgium,” Paedagogica Historica 53, no. 6 (2017): 720. 
Also evident is the images' focus on cleanliness and hygiene. The two photos portray settings that are clean and tidy. The large windows and the light evoke a sense of unpolluted air. These photos were intended as proof of sanitation and hygiene in these institutions. Public perceptions of the institution were created through imagery. The images do not portray happy or healthy children as evidence of the quality of the care or education offered by the institution. Rather, the images depict spacious rooms, heating, large windows and clean white sheets. The images highlight the clean, uniform and regulated settings that housed the admitted children. In this way, the images clarified the link between the institutions" "environmental design" and the "moral reformation" of their pupils and, by extension, their pupils' families. ${ }^{56}$

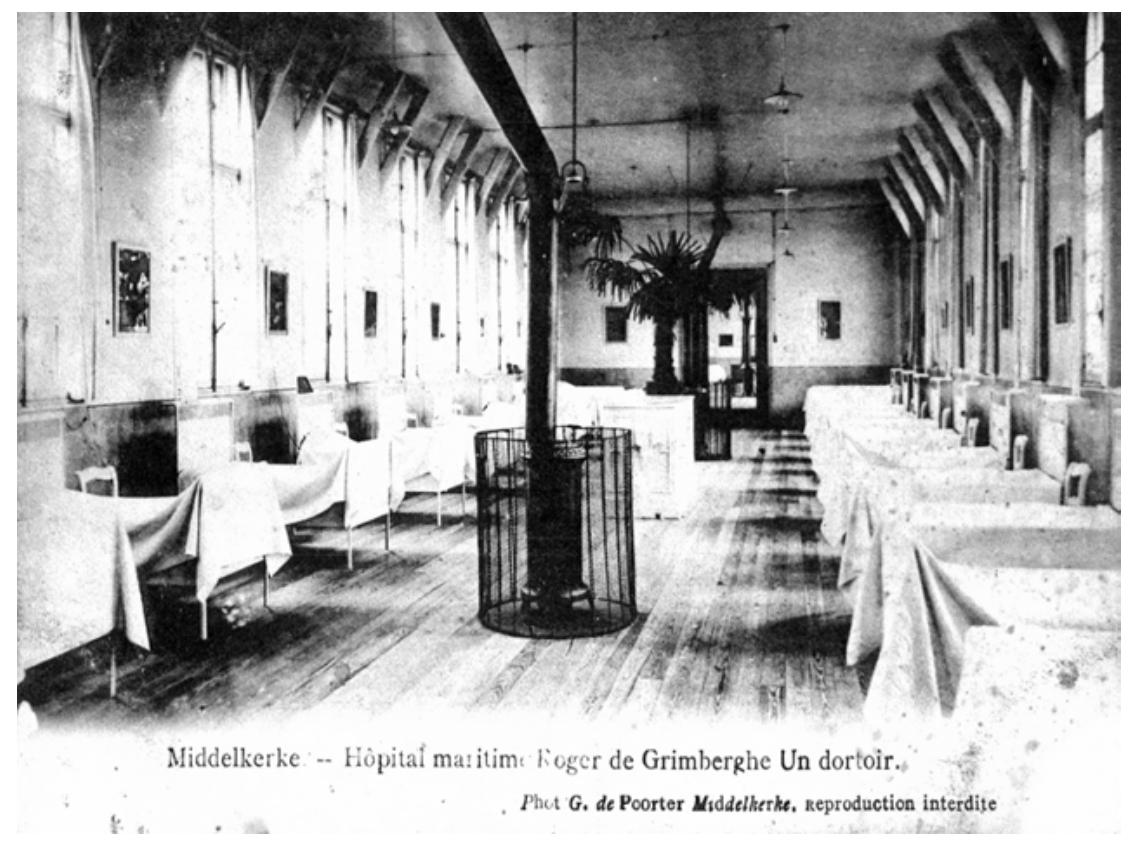

Fig. 2.2: Postcard of a children's dormitory in the seaside hospital of Middelkerke (the archive of Ronny Van Troostenberghe)

In the same vein, foster families would send pictures of the abandoned child that was placed in their family to health inspectors in order to demonstrate that the children were in good health. The photograph shown in Figure 2.3 is an ex-

56 Driver, Power and Pauperism, 14. 
ample of this. In January 1906, the foster parents of Polydore Raveel sent a photo of the young boy as proof that he had recovered from an obstinate disease. Polydore was born in Ghent on 8 December 1904. His mother died in the hospital shortly after giving birth at home and Polydore was registered as an abandoned child by the Ghent authorities. Already in bad health, he would be placed with three different foster families. The photograph was accompanied by a handwritten letter commenting on Polydore's good health. The letter noted that Polydore continued to suffer from a leg injury caused by his disease, which still affected his ability to walk. ${ }^{57}$

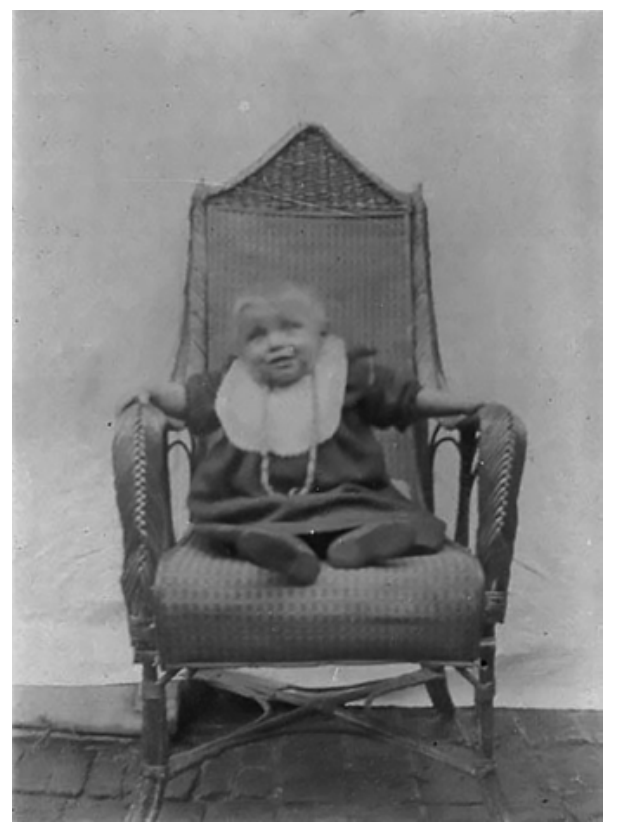

Fig. 2.3: Photo of Polydore Raveel (1906) (Archives of the Bureau of Social Welfare in Ghent)

The photos were staged to convey a specific message to the public. In this respect, the absence or presence of 'the child' in these photos communicates the intended mission of these initiatives. In this way, photographs served as instruments to display the successes of the reform project. The first two photographs analysed here were intended to persuade well-off citizens to donate to

57 Personal file Polydore Raveel (1904-1905), BG 14, n² 269, Council of Civil Hospices, Archives of the Bureau of Social Welfare, Ghent. 
the reform efforts, and parents to entrust the institutions with the care of their children. The photos' focus on the institutions' infrastructure legitimised the pedagogical interventions for children considered to be at risk-i.e. removal of the children from their parents and placement in institutions. ${ }^{58}$ The "aesthetic mission" of the photographs was linked inextricably to the "moral mission" of the reform projects. ${ }^{59}$

\section{The body}

As we can see in each of this contribution's case studies, attention to the children's health was a constant and central feature of the reform project. In the case of Ghent's abandoned children, for example, inspection visits focused mainly on health. Annual inspection reports by the inspection service of foundlings and abandoned children showed an increased focus on "l'état sanitaire" (health status) of the children. By the 1890s, a standardised inspection form was introduced. Items for observation included health, cleanliness, behaviour, character, morality and obedience. Correspondence from foster parents to the inspector focused mainly on the health of the foster child.

Foster parents used these letters to ask the inspector for advice and inform him of the child's development. The inspector would then respond to the parents with recommendations meant to keep the child healthy. Aside from this, the correspondence also included information about the height, weight and other physical features of the child, as well as the child's conduct at school and his or her writing and speaking skills. ${ }^{60}$ This allowed close observation of the physical and moral status of children placed with foster families in the countryside. André Turmel describes this focus on the health of at-risk children as "the medical gaze". ${ }^{61}$ During the second half of the $19^{\text {th }}$ century, children were increasingly viewed from a medical perspective. This perspective made children objects of

58 For international examples, see: Anne-Lise Head-König, "Les formes de garde des enfants placés en Suisse: politiques ambiguës, résistances et objectifs contradictoires (1850-1950)," Paedagogica Historica 46, no. 6 (2010): 763-773; Dekker, "Children at Risk in History: A Story of Expansion"; Christine Mayer et al., eds., Children and Youth at Risk; Nelleke Bakker et al., eds., Kinderen in Gevaar. De geschiedenis van pedagogische zorg voor risicojeugd; Timothy A. Hacsi, Second Home: Orphan Asylums and Poor Families in America (Cambridge: Harvard University Press, 1997).

59 Susan Sontag, On Photography (London: Penguin Books, 1979), 115.

60 See: inspection reports on the condition of the placed children (1893-1899), BG 14, n 283, Council of Civil Hospices, Archives of the Bureau of Social Welfare, Ghent.

61 Turmel, A Historical Sociology of Childhood, 77. 
systematic observation and classification, to be represented in charts and graphs.

In this vein, the professionalised mass observation of children in the late $19^{\text {th }}$ century became more scientific in its methods, techniques and procedures. No longer were paediatricians mainly concerned with a sound and scientific methodology for observing the child. Instead, their focus shifted to monitoring children in order to protect them against the worst social harms. This is evident in the evolution of the seaside hospital of Middelkerke. In the view of Dr. Casse, the value of the seaside hospital lay in its work as a scientific medical institute rather than in the services it provided to sick children. Casse envisioned Middelkerke as a hospital and not merely a site for convalescence. In his publications and letters to the General Council, he presented himself as a man of science who embraced a kind of medical activism. According to Casse, the seaside hospital was not a passive institution that provided supportive care. It was more akin to a traditional hospital, characterised by what Casse termed 'real' activities, such as medical treatment and experimental research. ${ }^{62}$

Casse distinguished between his hospital and Dr. Van Den Abeele's facility, the seaside hospital in Wenduine. The Wenduine hospital functioned more as an institution for feeble-minded children, with a focus on instruction and morality. The Middelkerke Seaside Hospital, according to Casse, had an entirely different mission. This perspective led the institution to select children based on age and abnormality. The standardisation and normalisation of children's developmental behaviour led to an expectation among medical and welfare experts that parents and children ought to conform to the averages represented in the charts. No longer did paediatricians merely observe and register. Now, they supervised and regulated child-rearing.

The malleability of the concept of 'the normal child' should be seen against the background of the broader expansion of the concept of normality in the $19^{\text {th }}$ century. This encompassed advances in observational methods to include different charts or graphs that measured items such as behaviour, skills and abilities. In this way, each addition to the notion of 'the normal child' relied on the establishment of a preceding construction. ${ }^{63}$ Subsequently, every deviation from the norm required an intervention to prevent further deviation. In each case study in this contribution, ideas of normal versus abnormal were translated into distinct criteria for inclusion and exclusion. Abandoned children, for example,

62 See: Admissions et placements, le nombre des enfants à traiter à Middelkerke (1884-1890), $n^{\circ} 260$, Council of Civil Hospices, General Fund, Archives of the Bureau of Social Welfare, Brussels.

63 Turmel, A Historical Sociology of Childhood, 183. 
were divided into three groups: children of normal health; children with physical defects but who were otherwise in good health, including children who were crippled, lame, beaten, obese, idiots, blind, or had deformed legs; and children suffering from disease, including scrofula, epilepsy, paralysis, incontinence, rickets, asthma or eye diseases. ${ }^{64}$

Most $19^{\text {th }}$-century crèches were private initiatives. For this reason, crèche owners decided which children to admit and which to reject based on objective criteria such as age, and on subjective criteria such as the good conduct of the mother. For example, the regulations of one day-care centre in the city of Ghent (1869) stipulated that it would only accept "children under two years of age, whose mothers are indigent, behave well and work outside the home". ${ }^{65}$ Other institutions, such as the crèche Louise-Marie (Ostend, 1898), stipulated similar criteria: "Only children under the age of three, from mothers that are poor and behave well, are accepted". ${ }^{66}$ In fact, in many crèches, it was customary to have the public authorities conduct an inquiry into the mother before accepting a child. ${ }^{67}$ In addition, many crèches required a recommendation from a member of the philanthropic or charitable association behind the day-care centre. Guidelines for one crèche in Brussels stipulated a recommendation by " $l a$ dame patronesse". In Liège, an inspector of the poor noted children's morality and their degree of misery, to be used as criteria for admission. ${ }^{68}$

In search of suitable foster families for abandoned children in Ghent, the inspector would also question prominent figures in the foster family's home town prior to and during placement. This might include the town's mayor, pastor, notary or the school director. In addition, the town's police would make inquiries into the family of the child, including a survey based on observation of the home and testimonies from neighbours. Observation, categorisation and standardisation of admitted children through instruments, inspections and surveillance were core elements in each of this contribution's case studies. The focus was not only on individual children's sick bodies, since their physical wellbeing

64 See: inspection reports on the condition of the placed children (1893-1899), BG 14, $\mathrm{n}^{\circ} 283$, Council of Civil Hospices, Archives of the Bureau of Social Welfare, Ghent.

65 Maatschappij van Weldadigheid voor het Stichten van Kinderkribben te Gent. Reglement van de kinderkrib (Ghent: MWSKG, 1869).

66 Albert Lecointe et al, Crèche Louise-Marie. Statuts \& Règlements. Arrêtés en Assemblée Générale le 16février 1899 (Ostend: Imprimerie Centrale Bouchery, 1899).

67 See: Elise Plasky, La protection et l'education de l'Enfant du Peuple en Belgique. I. Pour les Tout-Petits (Brussels: Société Belge de Librairie, 1909).

68 See: Perrine Humblet, “Analyse et évaluation de la mise en œuvre du programma de l'Euvre Nationale de l'Enfance pour les milieu d'accueil de jeunes enfants” (PhD. diss., Université Libre de Bruxelles, 1998). 
was thought to be closely related to their moral virtue. In this respect, the health of the parents was important as well, in addition to that of the child. In this way, the child's body represented the social collective body and its maladies. This is what made the directors of these initiatives small functionaries of "l'orthopédie morale". 69

\section{The bath}

The move towards a medical approach to the development of children as part of a larger project of social, medical and educational engineering made it possible to compare children with each other against different developmental criteria. Medical science offered novel insights on childhood through new methods, techniques and protocols. This process of scientification resulted in guidelines and detailed codes for children in care. For example, Henri Cazin (1836-1891), the doctor in charge at the sea hospital of the city of Paris in Berck-sur-Mer, developed a characterisation of different forms of bathing for different groups of children at risk. This resulted in a sort of typology of different kinds of baths for different kinds of children. ${ }^{70}$ The inspector of the abandoned children of Ghent also sent health regulations to foster parents and examined the physical wellbeing of children during visits. In 1904, the inspector of the Council of Civil Hospices, Jean Nové, outlined some health regulations that foster parents were required to follow closely in the event of illness among the abandoned children. The list included taking the child into the open air; frequent washing in cold water (especially the legs); and baths in lukewarm water, 20 minutes in duration and with one kilogram of kitchen salt in the bath water. ${ }^{71}$

The bath and the regulations on bathing are examples of what was seen as best practice at the time, particularly in the seaside hospitals. ${ }^{72}$ Emerging medical knowledge was translated into recommendations for a healthy daily life. Three factors were considered important with respect to bathing: water temperature, the water's salt and mineral content, and the strength of the water's

69 See: Michel Foucault, Surveiller et punir. Naissance de la prison (Paris: Gallimard, 1975). 70 Henry Cazin, De l'influence des bains de mer sur la scrofule des enfants (Paris: Asselin \& Houzeau, 1885), $76-77$.

71 List of Nové, 19 August 1904, Personal file Adrienne De Mets, BG 14, n² 243, Council of Civil Hospices, Archives of the Bureau of Social Welfare, Ghent.

72 Bruno Vanobbergen, "Changing Perspectives on the Child at Risk at the End of the Nineteenth Century. The Belgian Maritime Hospital Roger De Grimberghe (1884-1914) as a Space of Inclusion and Exclusion,” Disability \& Society 24, no. 4 (2009): 425-436. 
waves. Waves, for example, were seen as conferring strength and balance. Casse outlined some principles to be followed when bathing. For example, certain periods of the year were best suited to bathing in the sea. The ideal duration of baths was studied, as was the time of the day best suited to bathing. Medicalised regulations were also applied to crèches in the early days of Belgian day-care. Children received fresh clothes when they arrived in the crèche, and their cradles were separated from each other. Their daily clothes were disinfected, and the children themselves received a thorough wash every day. ${ }^{73}$

By the beginning of the $20^{\text {th }}$ century, reformers were, through written manuals and guidelines, in a position of "creating and implementing social devices and technologies to frame the behaviour of children as well as that of their parents". ${ }^{74}$ Regulations on bathing were not only examples of what was seen as best practice at the time, particularly in the seaside hospitals. ${ }^{75}$ 'The bath' can also be used as a metaphor for social reform and moral purification. The belief in enhancing children's welfare by putting them in a healthy environment was the foundation of all three initiatives. Daily rituals and health regulations to cure these children of what Felix Driver calls "anti-social behaviour"76 were pivotal to the reform project. The medical practices that took place in these three research cases clearly functioned as normalising techniques and served a dual goal. Of course, the promotors were striving for an enhancement of the children's physical status. Nevertheless, the emphasis was much more on moulding the children's hearts and souls. By removing the children from their families and by putting them in a 'healthy' setting, far away from all dangers of their life in the city, the hope existed of generating virtuous citizens.

\section{Conclusion}

The strategic approach of these initiatives is clear: the physical cleansing of children in care would lead to moral purification of the pupils and future citizens. In time, this attention to the moral health of children at risk would spread, through their parents, into society. The origin of the idea of the child at risk is situated by most authors in the beginning of the $19^{\text {th }}$ century, when numerous initiatives were developed for abandoned children, foundlings, vagrants and orphans in order to redeem morally endangered children for the benefit of society. Case

73 E Hommelen, “Gezondheidsorganisatie in kinderkribben,” Het Kind (1961): 245-253.

74 Turmel, A Historical Sociology of Childhood, 114.

75 Vanobbergen, "Changing Perspectives on the Child at Risk".

76 Driver, Power and Pauperism, 23. 
studies of three institutions for at-risk children - the seaside hospitals, the care for the abandoned children of Ghent and the first Belgian crèches - show that the risks of future contamination of society were curtailed by reforming at-risk children and making their parents invisible. By categorising this group of children as poor, ill and parentless, reformers created the idea of an entity separate from other members of society. At the same time, reformers suggested that, through intervention and assistance, at-risk children could escape from their fate and become virtuous citizens after all. ${ }^{77}$ This chapter examined three procedures or practices of this reform project.

Initiatives to reduce the number of children at risk led to the conception of new categories of children at risk. In this way, although initiatives to care for atrisk children arose from the desire to reduce their numbers, the history of the child at risk has become one of ongoing expansion. ${ }^{78}$ Today, the creation of categories of at-risk children continues to lead to the creation of institutions and measures to eliminate these risks. In that sense, 'at risk' has had, and continues to have, different meanings. Having shown that the idea of 'risk' or of 'being at risk' has been used in different settings, we conclude that the evolution of the idea of the child at risk continues today. In fact, never before in history have more children been diagnosed as at risk. ${ }^{79}$

Our analysis of reform programs through the 'child as a sick body' perspective of these initiatives has outlined perceptions of good education and, in turn, of good parenting. The images, the inclusion and exclusion mechanisms of reform initiatives, and the health regulations analysed in this chapter, contributed to the idea that at-risk children had 'deserving' or 'undeserving' parents. This distinction is evident in Western societies throughout history. This attitude ignores the fact that poverty is a social problem, not a moral one. Today, social policy makers and organisations continue to label children and frame their potential risk to society through the rhetoric of class, poverty or disease to distance children from their families and legitimise intervention.

77 See: Lydia Murdoch, Imagined Orphans. Poor Families, Child Welfare, and Contested Citizenship in London (New Brunswick: Rutgers university press, 2006).

78 Dekker, "Children at Risk in History".

79 Paul Smeyers, “Child Rearing in the 'Risk' Society: On the Discourse of Rights and the 'Best Interests of a Child”, Educational Theory 60 (2010): 271-284; Dekker, “Children at Risk in History". 